$\angle$ Research Square

\section{Impact of ICT on Environment}

\section{Samaneh Mahdavi}

Allameh Tabataba'i University

Sakineh Sojoodi ( $\nabla$ sakinehsojoodi@gmail.com )

University of Tabriz https://orcid.org/0000-0002-2109-3555

\section{Research Article}

Keywords: Information and Communications Technologies, ICT, IDI, CO2, energy consumption, Generalized Method of Moments, GMM

Posted Date: October 27th, 2021

DOI: https://doi.org/10.21203/rs.3.rs-1020622/v1

License: () (1) This work is licensed under a Creative Commons Attribution 4.0 International License. Read Full License
Preprints are preliminary reports that have not undergone peer review.

They should not be considered conclusive, used to inform clinical practice, or referenced by the media as validated information. 


\section{Abstract}

The impact of information and communications technologies (ICT) on the environment is a complex highly-debated subject. Indeed, ICT can have both positive and negative impacts on the environment. While ICT tools and devices can be used to improve energy efficiency, which results in reduced $\mathrm{CO}_{2}$ emissions and environmental degradation, the manufacturing and use of ICT devices can become a major source of emission. Also, many ICT devices contain non-renewable and non-recyclable components that can cause significant environmental damage. Therefore, one may question that whether ICT improves environmental quality in countries with different income levels? To answer this question, this study investigated the environmental impacts of ICT in three groups of high, middle, and low-income countries from 2005 to 2019 using the Generalized Method of Moments (GMM). The ICT Development Index (IDI) was used as the measure of ICT development. Empirical results showed that the use of ICT led to reduced total $\mathrm{CO}_{2}$ emissions, $\mathrm{CO}_{2}$ emissions from solid fuel consumption, $\mathrm{CO}_{2}$ emissions damage, particulate emissions damage, and energy consumption in the studied countries. Therefore, ICT was found to have a generally negative (favorable) impact on environmental degradation in these countries. Considering this effect of ICT on environmental degradation and pollution, governments are recommended to pursue their energy consumption and emission objectives by promoting the use of ICT in the environmental sector and the implementation of green ICT projects.

\section{Introduction}

Given the remarkably fast advancement of Information and Communications Technologies (ICT) in recent years, the digitalization of the economy is expected to accelerate over the upcoming decades. These developments, along with the intensification of environmental issues like climate change, highlight the need for more research into the potential environmental impacts of ICT. While the amount of greenhouse gas (GHG) emissions produced from or as a result of ICTrelated products or activities throughout their life cycle is an important issue (Freitag et al., 2021), so is the capability of ICT in reducing energy consumption and counteracting rising energy costs (Wong \& Schuchard, 2011). Indeed, some ICT-based solutions introduced in recent decades have been very successful in reducing GHG emissions in certain fields, resulting in a positive impact on the environment. For example, the use of e-mail instead of physical mail has reduced the consumption of paper and fuel. Also, ICT allows all transactions to be conducted online without the need for physical travel. ICT has also provided a platform for automated and intelligent solutions in the fields of electricity generation, agriculture, etc., which tend to reduce GHG emissions (Bekaroo et al., 2016).

Today, the world faces several major environmental crises, some of which seem to be irreversible. Identifying the factors that can intensify or reduce these environmental damages is essential for saving the planet and humankind from the consequences of these crises. Considering the variety of environmental and energy issues facing the world today and the potential positive and negative effects of ICT on the environment, in this study, we have tried to conduct a thorough investigation of the general environmental impacts of ICT. The innovation of this study was the analysis of 30 countries selected from three different income groups and periods (2005-2019), including high-, middle-, and low-income nations. Moreover, the effect of the combination of variables recruited, containing population variables, industry value-added, and GDP along with ICT development index on several groups of environmental components (namely, carbon dioxide $\left[\mathrm{CO}_{2}\right]$ emissions, $\mathrm{CO}_{2}$ emissions from solid fuel consumption, damages from $\mathrm{CO}_{2}$ emissions, energy consumption, and emissions of suspended particulates) was examined separately in five different equations using the panel generalized method of moments (GMM).

There are various views and theories regarding the role of ICT in environmental changes in terms of energy consumption and emissions, some of which will be discussed in the following section along with the existing empirical evidence. In the third section, the research model and analysis method are introduced and then the empirical findings are presented.

\section{Review Of Literature}

ICT has had revolutionizing impacts in countless economic, social, and environmental dimensions, which have transformed the world into an information society. The relationship of ICT with the environment is a complex and multidimensional issue. ICT can have both positive and negative effects on environmental sustainability. ICT gives communities a powerful tool to protect the environment around them. It also gives humans the means to reduce their need for natural sources and the amount of waste they release into the environment. However, it takes significant amounts of energy and resources to develop, manufacture, and distribute ICT devices and equipment, and since these devices tend to have a short lifespan, the development of ICT has also increased the amount of electronic waste that is released into the environment. The positive and negative effects of ICT on the environment are usually divided into three broad categories provided in Table 1. The first two categories, which can be both positive and negative, are the first-order or direct impacts (e.g. energy consumption by ICT devices and the use of ICT in environmental monitoring and control) and the second-order or indirect impacts (e.g. the effect of ICT on the transportation efficiency and thus the pollution caused by fuel consumption). The third category of effects, which are known as systemic (rebound) impacts, refers to the mostly negative outcomes that follow the direct or indirect impacts of ICT on the environment (e.g. increased production with advanced ICT-based production equipment due to ease of working with this equipment). 
Table 1

Environmental impacts of ICT

\begin{tabular}{|lll|}
\hline & Positive impacts & Negative impacts \\
\hline $\begin{array}{l}\text { The first-order or } \\
\text { direct impacts }\end{array}$ & The use of ICT in environmental monitoring and control & $\begin{array}{l}\text { Environmental impacts of the manufacturing and use of ICT } \\
\text { devices and equipment (e.g. generation of electronic waste) }\end{array}$ \\
$\begin{array}{l}\text { The second-order } \\
\text { or indirect impacts }\end{array}$ & $\begin{array}{l}\text { Structural changes and resource conservation (a reduction in } \\
\text { the amount of resources consumed in the economy) }\end{array}$ & $\begin{array}{l}\text { Incomplete substitution of goods and services with ICT } \\
\text { Systemic or rebound impacts }\end{array}$ \\
& \\
\hline $\begin{array}{l}\text { The third-order } \\
\text { impacts }\end{array}$ & $\begin{array}{l}\text { Lifestyle changes (e.g. directing consumption towards green } \\
\text { and environment-friendly consumption) }\end{array}$ \\
\hline Source: Organization for Economic Co-operation and Development (OECD, 2001) & \\
\hline
\end{tabular}

\subsection{Relationship between ICT and $\mathrm{CO}_{2}$ emissions}

Research has shown that the positive and negative effects of ICT on $\mathrm{CO}_{2}$ emissions can be related to a wide variety of factors. Provided in the following are a few examples of studies conducted in this area.

ICT-based tools can affect the amount of pollution vehicles release into the air by changing driver behavior and enabling and encouraging environmentfriendly driving. These tools include navigation and travel information, traffic management and control, demand and access management, and advanced driver assistance systems. Thus, ICT has indeed the potential to reduce $\mathrm{CO}_{2}$ emissions (Monzon et al., 2017). In a study by Lopez et al. (2011) on the effect of the composition of public spending on environmental quality, it was shown that increasing government spending in areas such as environmental protection and communications tends to result in reduced $\mathrm{CO}_{2}$ emissions. In another study on the environmental effects of ICT, Auci \& Becchetti (2005) investigated the effects of variables such as the number of radio receivers and landlines per 1,000 people on $\mathrm{CO}_{2}$ emissions in 197 countries. The results of this study showed the negative impact of both factors on $\mathrm{CO}_{2}$ emissions. Moyer \& Hughes (2012) investigated the dynamic effects of ICT in the economic and energy sectors and the resulting $\mathrm{CO}_{2}$ emissions. In the end, this study concluded that ICT will reduce the overall amount of $\mathrm{CO}_{2}$ to be emitted over a 50 -year time period. In a study by Chowdhury (2012), it was shown that proper use of ICT can reduce the GHG emissions of commercial and service sectors. This study also showed how Green Information Technology (Green IT) and cloud computing technologies can be used to optimize the use of ICT and ultimately reduce GHG emissions through an environment-friendly information retrieval (IR) system. By introducing the concept of Green IR systems and services, this study highlighted the potential role of these factors in reducing the environmental impact of ICT-based services in the fields of education, research, business, government, etc. It also demonstrated that green IT and cloud computing can play a notable role in reducing the environmental impact of ICT. A study by Stewart (2015) examined the impact of ICT and ICT-based measures on $\mathrm{CO}_{2}$ emissions through the improvement of bus travel time and car-sharing in the European Union. The result of this study showed that ICT measures have a more significant effect on $\mathrm{CO}_{2}$ emissions through reduced car use than through improved public transport (bus) travel time. A study by Zhang \& Liu (2015) investigated the impact of ICT on $\mathrm{CO}_{2}$ emissions in China at national and regional levels with due consideration of major regional differences that exist in different parts of this country. The results of the study showed that the ICT industry has a positive (reducing) impact on $\mathrm{CO}_{2}$ emissions and this impact is greater in central China than in the east and is relatively negligible in the west. In this regard, the empirical results of a study by Higón et al. (2017) on the relationship between ICT and $\mathrm{CO}_{2}$ emissions on the global scale showed that after reaching a certain level of ICT development, ICT starts to reduce $\mathrm{CO}_{2}$ emissions. These researchers reported that in both developed and developing countries, ICT has an inverted U-shaped relationship with $\mathrm{CO}_{2}$ emissions. From this, it can be inferred that with the further development of the ICT sector and changes in the economic structure, it becomes easier to pursue environmental sustainability. In a study by Asongu et al. (2018), they investigated how increasing ICT penetration may contribute to environmental sustainability in sub-Saharan Africa (SSA) by reducing $\mathrm{CO}_{2}$ emissions. This study examined two indicators of ICT penetration, namely Internet penetration and mobile phone penetration, in 44 countries. In this study, non-interactive regressions suggested that ICT does not have a significant effect on $\mathrm{CO}_{2}$ emissions. But interactive regressions showed that ICT has a net positive effect on $\mathrm{CO}_{2}$ emissions. However, increased mobile phones penetration alone did not have a net negative effect on $\mathrm{CO}_{2}$ emissions. This study also reviewed the policies that can be utilized to deduce the negative impact of ICT on $\mathrm{CO}_{2}$ emissions. Zhou et al. (2019) studied the $\mathrm{CO}_{2}$ emissions of multiple sub-sectors of ICT in China. The results of this study show that considering its inherent carbon impacts, the ICT sector is very environmentally friendly, as it can significantly reduce $\mathrm{CO}_{2}$ emissions. Haini (2021) examined the impact of ICT and human capital on $\mathrm{CO}{ }_{2}$ emissions in ASEAN economies. The results of this study suggested that ICT reduces $\mathrm{CO}_{2}$ emissions through innovative technologies. This is evident in the fact that $\mathrm{CO}_{2}$ emission has plummeted during the COVID-19 pandemic because of increased online activity. However, the impact of human capital differs from sector to sector. This study reported that the development of human capital leads to reduced $\mathrm{CO}_{2}$ emission in the manufacturing sector but increases it in the residential and transportation sectors. Overall, the findings of this study suggested that the development of a strong ICT sector with high levels of human capital can potentially reduce $\mathrm{CO}_{2}$ emissions. Khan et al. (2018) studied the relationship between the factors of ICT, economic growth, financial development, and environmental quality in emerging economies. The findings of this study showed that: 1) The effect of ICT on $\mathrm{CO}_{2}$ emissions is significant, 2) The moderating effect of ICT and financial development stimulates $\mathrm{CO}_{2}$ emissions, and 3) economic growth increases $\mathrm{CO}_{2}$ emissions. However, the interactive effect of ICT and GDP leads to reduced pollution. Likewise, the use of smart technologies such as smart home appliances, smart transportation, and smart electricity services reduces $\mathrm{CO}_{2}$ emissions. Also, in emerging economies, the use of energy-efficient ICT devices results in reduced carbon levels. Also, the use of ICT devices with lower energy consumption (e.g. smart networks) inhibits global $\mathrm{CO}_{2}$ emissions (Ozcan \& Apergis, 2018).

Page 3/18 
Many researchers have reported on the destructive effects of ICT on the environment. For example, according to Kumar \& Mieritez (2007), 1-3\% of global GHG emissions are related to the manufacturing and use of ICT devices and equipment. Costantini \& Martini (2006) reported that the number of Internet lines, landlines, and mobile phones per 1000 people has a positive impact on the emission of various pollutants, including $\mathrm{CO}_{2}$. According to some studies, ICT has much greater negative effects in developing countries than in the developed world. According to Majeed \& Tariq (2018), while in developed countries, ICT helps maintain environmental sustainability, in developing countries, it has a devastating effect on the environment. Since many ICT-related tools used in developed countries have a negative impact on $\mathrm{CO}_{2}$ emissions, more investment in ICT in these countries tends to contribute to environmental sustainability. But, such investments will have the opposite effect in developing countries, as they do not have the necessary capabilities to fully utilize ICT. Furthermore, these countries have much poorer electronic waste management capabilities. In this regard, the results of a study by Lashkarizadeh \& Salatin (2012) also highlighted the difference between the effectiveness of ICT in developed and developing countries. According to this study, although ICT is a negative factor for pollution in both developed and developing countries, its impact is different in these countries. In developed countries, ICT has a much greater effect on reducing air pollution and investment in ICT per GDP leads to a greater reduction in $\mathrm{CO}_{2}$ emissions (compared to developing countries). The difference between developed and developing countries in terms of $\mathrm{CO}_{2}$ emissions is mainly due to the migration of polluting industries from developed countries to developing countries because of cost advantages and environmental regulations. This trend functions as a contributor to environmental pollution in developing countries but has the opposite effect in developed countries. In a study by Bekaroo et al. (2016), these researchers investigated the factors that influence $\mathrm{CO}_{2}$ emission reduction by examining the complex relationship between ICT, climate change, and society using the knowledge-implementation-effect (KIE) cycle. These researchers studied various ICT-related methods that can be used to help reduce $\mathrm{CO}_{2}$ emissions. The analyses of this study showed that the lack of knowledge is a key obstacle to the implementation of environmentally sustainable techniques, or in other words, poor knowledge prevents the sustainable use of ICT to reduce $\mathrm{CO}_{2}$ emissions. Amri et al. (2019) also studied the relationship between $\mathrm{CO}_{2}$ emissions and total factor productivity (TFP) as well as ICT in Tunisia. The results of this study rejected the validity of the environmental Kuznets curve (EKC) and showed the small effect of ICT on $\mathrm{CO}_{2}$ emissions as a measure of pollution. In another study, Avom et al. (2020) investigated the effect of ICT and ICT transmission channels on $\mathrm{CO}_{2}$ emissions. This study reported that the two used ICT indicators, namely mobile phone penetration and Internet penetration, have a relationship with $\mathrm{CO}_{2}$ emissions. This study also showed the direct and indirect positive effects of ICT on $\mathrm{CO}_{2}$ emissions. This positive effect suggests that the environmental quality in the studied countries deteriorates with the improvement of ICT indicators. A study by Marin (2010) on the factors influencing the emission of pollutants in the Italian industrial sector showed a statistically insignificant relationship between ICT and $\mathrm{CO}_{2}$ and SOX emissions.

\subsection{Relationship between ICT and energy cost and consumption}

The use of ICT can benefit or hurt the energy sector in various ways. The development of ICT affects energy consumption in two ways: 1) ICT reduces energy consumption by providing a platform for wireless information exchange. For example, in the field of education, it enables students to use distance learning services. In the field of business, ICT allows most purchases and transactions to be made online or electronically, which greatly reduces the need for physical transport. 2) ICT increases energy consumption by increasing the use of electronic devices. Indeed, electronic devices are expected to account for a major portion of total power consumption in the future (Wang \& Han, 2016). ICT can also be used to make technologies more energy efficient in order to fight climate change. For example, it has the ability to minimize energy loss and improve the efficiency of energy generation, storage, and distribution systems. ICT can also be used to reduce the energy consumption of construction and transportation sectors with the ultimate goal of alleviating the effects of climate change (Asian Disaster Preparedness Center, 2013). ICT can have a major environmental impact in relation to climate change. This technology can help achieve enhanced energy efficiency in buildings and transportation sectors through dematerialization and teleworking. ICT also allows for creating smart grids with better monitoring and control capabilities, which leads to reduced energy loss, higher operational efficiency, better energy supply quality, greater control over energy consumption, better management of power sources, and reduced GHG emissions. In relation to buildings, ICT can be used to create smart systems for automatic management of lighting, heating, and cooling devices and measuring the energy efficiency of buildings (Houghton, 2010). In a review of the literature on the effect of ICT on the environmental impacts of energy consumption, Bastida et al, (2019) reported that ICT has a positive effect on reducing power consumption, improving energy efficiency, and reducing GHG emissions in the European Union. The results of this study showed the positive effect of ICT on the pattern of energy consumption in the household sector and ultimately the GHG emissions of the power generation sector. In a study by Schulte et al. (2014) on the relationship between ICT and overall energy demand, it was concluded that there is a negative relationship between these factors. After examining the relative demand for electrical and non-electrical energy, these researchers reported that while there is no significant relationship between the use of ICT and the demand for electrical energy, the demand for non-electric energy decreases significantly with the increase in ICT use. These results can be used to decide on the matters relating to the substitution and complementation of electricity and fuels. Since fuel consumption tends to cause air pollution, whereas electricity consumption has much less or zero pollution, the negative relationship between ICT and non-electricity energy demand is environmentally beneficial. A study by Han et al. (2016) on the role of ICT in China confirmed the significant negative impact of ICT on short-term energy consumption in this country. According to these researchers, ICT-based wireless information exchange possibilities have changed the way newspapers are read and the patterns of business travels, leading to higher energy conservation. Indeed, ICT provides a platform for online shopping, remote communications, videoconferencing, and virtual meetings and conferences, which reduce the need for travel and, consequently, the amount of energy consumed in the transportation sector.

While the above studies have highlighted how ICT can reduce energy consumption, another group of studies have pointed out the negative effects of ICT on energy cost and consumption and the environmental impacts of these effects.

For example, a study by Sadorsky (2012) on the impact of ICT on power consumption in emerging economies showed a significant positive relationship between ICT and electricity consumption in these countries. The indicators of ICT in this study were Internet connectivity, mobile phones, and personal computers. The study of Arushanyan et al. (2014) on the effects of ICT products and services also showed that the use of these products and services has a notable impact on global energy consumption and global warming. The efficiency improvement resulting from the use of ICT can lead to reduced energy costs, which will ultimately lead to increased energy consumption. This is known as the rebound impact. The development of ICT also affects people's 
lifestyles, leading to increased demand for ICT products and, consequently, increased energy consumption in the manufacturing of these products. Furthermore, the high ICT-dependence of production processes can lead to higher energy consumption in this sector.

\subsection{Relationship between ICT and ecology and agriculture}

Regarding the impact of ICT on ecology and agriculture, a study by Yilmaz et al (2019) showed that ICT has a positive (reducing) effect on deforestation. ICT can benefit forestry in a variety of ways, for example by making it easier to map and monitor forest hazards and threats and prevent illegal logging and fires. In a study by Bonvoisin et al. (2014), these researchers provided an integrated framework for the environmental design and assessment of ICT-based optimization services at three levels of equipment, infrastructure, and information and introduced such an optimization service for municipal waste collection at the city level.

The negative environmental effects of ICT include the use of non-renewable and environmentally damaging resources such as lead and mercury and the pollution caused by the disposal of electronic and non-electronic wastes. Another negative environmental effect of ICT is the increased use of paper in small printers (Rodhain \& Fallery, 2013). Also, incineration of ICT devices along with other wastes can lead to the release of hazardous compounds such as brominated dioxins and furans. Another environmental issue of ICT devices and equipment is that many of them cannot be easily recycled (European Union, 2021). In fact, improper recycling of these devices in developing countries can be a significant source of environmental pollution (Williams, 2011).

ICT has had a substantial positive impact on the improvement of agricultural processes. For example, ICT grants farmers the knowledge and information they need to produce more valuable crops, reduce production costs, increase sales prices, and use less herbicide and pesticide. Also, farmers can use ICT to gain better climate, natural resource, and other farming-related information (Das \& Kabir, 2016). ICT can also benefit agricultural marketing in two ways: 1) providing real-time access to information about market demand, 2) providing long-term market trend information for easier planning. Mobile phones, for example, have become a handy tool for gaining market knowledge and insight. Past studies in this field have shown that ICT-based market information services improve the efficiency of agricultural markets (Kamande \& Nafula, 2016).

While most of the above studies have been focused on the role of ICT in environmental development and the mitigation of environmental damages in this area, several articles have highlighted how ICT has hurt the environment by accelerating GHG emissions and energy consumption. However, the present article assumes that the implementation of ICT-based innovations and policies can have a net positive effect on the environment.

The aforementioned positive and negative environmental impacts of ICT in different sectors are summarized in the following tables. 
Table 2

Impacts of ICT on $\mathrm{CO}_{2}$ emissions

\begin{tabular}{|c|c|c|c|c|}
\hline $\begin{array}{l}\mathrm{CO}_{2} \\
\text { emissions }\end{array}$ & Positive Impacts & Source & Negative Impacts & Source \\
\hline & ICT tools can help reduce air pollution & $\begin{array}{l}\text { Monzon et } \\
\text { al., } 2017\end{array}$ & $\begin{array}{l}\text { According to non-interactive regressions, ICT has no } \\
\text { significant effect on } \mathrm{CO}_{2} \text { emissions in Africa }\end{array}$ & $\begin{array}{l}\text { Asongu et al. } \\
(2018)\end{array}$ \\
\hline & $\begin{array}{l}\text { ICT increases government spending on } \\
\text { environmental protection and communications }\end{array}$ & $\begin{array}{l}\text { Lopez et } \\
\text { al., } 2011\end{array}$ & $\begin{array}{l}\text { The manufacturing and use of ICT devices account } \\
\text { for } 1-3 \% \text { of global GHG emissions }\end{array}$ & $\begin{array}{l}\text { Kumar \& } \\
\text { Mieritez } \\
\text { (2007) }\end{array}$ \\
\hline & $\begin{array}{l}\text { There is an inverse relationship between the } \\
\text { penetration of radio receivers and landlines and } \\
\mathrm{CO}_{2} \text { emissions }\end{array}$ & $\begin{array}{l}\text { Auci \& } \\
\text { Becchetti, } \\
(2005)\end{array}$ & $\begin{array}{l}\text { The undesirable impact of ICT on the emission of } \\
\text { pollutants, including } \mathrm{CO}_{2} \text {, is greater in developing } \\
\text { countries }\end{array}$ & $\begin{array}{l}\text { Costantini \& } \\
\text { Martini (2006) }\end{array}$ \\
\hline & $\begin{array}{l}\text { There is an inverse relationship between ICT and } \\
\mathrm{CO}_{2} \text { emissions over the next } 50 \text { years }\end{array}$ & $\begin{array}{l}\text { Moyer\& } \\
\text { Hughes } \\
\text { (2012) }\end{array}$ & $\begin{array}{l}\text { Investments in ICT in developing countries increase } \\
\mathrm{CO}_{2} \text { emissions }\end{array}$ & $\begin{array}{l}\text { Majeed \& } \\
\text { Tariq, } 2018\end{array}$ \\
\hline & $\begin{array}{l}\text { ICT reduces GHG emission of commercial and } \\
\text { service sectors }\end{array}$ & $\begin{array}{l}\text { Chowdhury } \\
\text { (2012) }\end{array}$ & $\begin{array}{l}\text { ICT has less impact on reducing } \mathrm{CO}_{2} \text { emissions in } \\
\text { developing countries than in developed countries }\end{array}$ & $\begin{array}{l}\text { Lashkarizadeh } \\
\text { \& Salatin, } \\
2012\end{array}$ \\
\hline & $\begin{array}{l}\text { ICT reduces } \mathrm{CO}_{2} \text { emissions by decreasing vehicle } \\
\text { use }\end{array}$ & $\begin{array}{l}\text { Stewart } \\
(2015)\end{array}$ & $\begin{array}{l}\text { The lack of knowledge is an obstacle to the } \\
\text { sustainable use of ICT to reduce } \mathrm{CO}_{2} \text { emissions }\end{array}$ & $\begin{array}{l}\text { Bekaroo et al. } \\
(2016)\end{array}$ \\
\hline & ICT industry reduces $\mathrm{CO}_{2}$ emissions in China & $\begin{array}{l}\text { Zhang \& } \\
\text { Liu (2015) }\end{array}$ & ICT has a negligible impact on $\mathrm{CO}_{2}$ emissions & $\begin{array}{l}\text { Amri et al. } \\
(2019)\end{array}$ \\
\hline & $\begin{array}{l}\text { The development of the ICT sector leads to reduced } \\
\mathrm{CO}_{2} \text { emissions in both developed and developing } \\
\text { countries }\end{array}$ & $\begin{array}{l}\text { Higón et al. } \\
\text { (2017) }\end{array}$ & $\begin{array}{l}\text { Two indicators of ICT have an impact on the } \\
\text { increase in } \mathrm{CO}_{2} \text { emissions and deterioration of } \\
\text { environmental quality }\end{array}$ & $\begin{array}{l}\text { Avom et al. } \\
(2020)\end{array}$ \\
\hline & $\begin{array}{l}\text { According to interactive regressions, ICT reduces } \\
\mathrm{CO}_{2} \text { emissions in Africa }\end{array}$ & $\begin{array}{l}\text { Asongu et } \\
\text { al. (2018) }\end{array}$ & $\begin{array}{l}\text { An insignificant relationship between ICT and } \mathrm{CO}_{2} \\
\text { and SOX emissions }\end{array}$ & Marin (2010) \\
\hline & $\begin{array}{l}\text { Environmental adaptability of the ICT sector in } \\
\text { terms of reducing the effects of } \mathrm{CO}_{2} \text { emissions }\end{array}$ & $\begin{array}{l}\text { Zhou et al. } \\
\text { (2019) }\end{array}$ & & \\
\hline & $\begin{array}{l}\text { Developing a strong ICT sector with high levels of } \\
\text { human capital reduces } \mathrm{CO}_{2} \text { emissions }\end{array}$ & $\begin{array}{l}\text { Haini } \\
(2021)\end{array}$ & & \\
\hline & $\begin{array}{l}\text { Using ICT to build smart grids reduces } \mathrm{CO}_{2} \\
\text { emissions }\end{array}$ & $\begin{array}{l}\text { Khan et al., } \\
2018\end{array}$ & & \\
\hline & $\begin{array}{l}\text { The use of energy-efficient ICT devices in emerging } \\
\text { economies reduces their } \mathrm{CO}_{2} \text { emissions }\end{array}$ & $\begin{array}{l}\text { Ozcan \& } \\
\text { Apergis, } \\
2018\end{array}$ & & \\
\hline
\end{tabular}

Table 3

Impacts of ICT on energy cost and consumption

\begin{tabular}{|c|c|c|c|c|}
\hline \multirow{8}{*}{$\begin{array}{l}\text { Energy cost } \\
\text { and } \\
\text { consumption }\end{array}$} & Positive Impacts & Source & Negative Impacts & Source \\
\hline & $\begin{array}{l}\text { Wireless information technologies reduce energy } \\
\text { consumption }\end{array}$ & $\begin{array}{l}\text { Wang \& Han, } \\
2016\end{array}$ & ICT increases energy consumption & $\begin{array}{l}\text { Wang \& } \\
\text { Han, } 2016\end{array}$ \\
\hline & $\begin{array}{l}\text { ICT reduces energy loss in the manufacturing, construction, } \\
\text { and transportation sectors }\end{array}$ & $\begin{array}{l}\text { Asian disaster } \\
\text { preparedness } \\
\text { center, } 2013\end{array}$ & $\begin{array}{l}\text { There is a significant positive } \\
\text { relationship between ICT and } \\
\text { electricity consumption }\end{array}$ & $\begin{array}{l}\text { Sadorsky } \\
(2012)\end{array}$ \\
\hline & $\begin{array}{l}\text { ICT reduces energy loss by creating intelligent networks and } \\
\text { automated lighting, heating, and cooling management } \\
\text { systems }\end{array}$ & $\begin{array}{l}\text { Houghton, } \\
2010\end{array}$ & $\begin{array}{l}\text { The use of ICT products plays a } \\
\text { notable role in global energy } \\
\text { consumption and global warming }\end{array}$ & $\begin{array}{l}\text { Arushanyan } \\
\text { et al. }(2014)\end{array}$ \\
\hline & $\begin{array}{l}\text { ICT reduce electricity consumption, improve energy } \\
\text { efficiency and reduce GHG emissions by changing the } \\
\text { pattern of household energy consumption }\end{array}$ & $\begin{array}{l}\text { Bastida et al. } \\
\text { (2019) }\end{array}$ & & \\
\hline & $\begin{array}{l}\text { 1) There is a negative relationship between ICT and electrical } \\
\text { energy demand }\end{array}$ & $\begin{array}{l}\text { Schulte et } \\
\text { al.,2014 }\end{array}$ & & \\
\hline & $\begin{array}{l}\text { 2) There is a negative relationship between ICT and non- } \\
\text { electrical energy demand }\end{array}$ & & & \\
\hline & $\begin{array}{l}\text { ICT has a significant negative impact on short-term energy } \\
\text { consumption in China }\end{array}$ & Han et al., 2016 & & \\
\hline
\end{tabular}


Table 4

Impacts of ICT on ecology and agriculture

\begin{tabular}{|c|c|c|c|c|}
\hline $\begin{array}{l}\text { Ecology } \\
\text { and } \\
\text { agriculture }\end{array}$ & Positive Impacts & Source & Negative Impacts & Source \\
\hline & ICT effectively reduces deforestation & $\begin{array}{l}\text { Yilmaz et } \\
\text { al.,2019 }\end{array}$ & ICT enables the wasteful use of paper in printers & $\begin{array}{l}\text { Rodhain \& } \\
\text { Fallery, } \\
2013\end{array}$ \\
\hline & $\begin{array}{l}\text { Support for the eco-friendly design of ICT-based } \\
\text { optimization services }\end{array}$ & $\begin{array}{l}\text { Bonvoisin et } \\
\text { al. (2014) }\end{array}$ & $\begin{array}{l}\text { 1) Incineration of ICT devices will release dangerous } \\
\text { compounds } \\
\text { 2) ICT devices are difficult to recycle }\end{array}$ & $\begin{array}{l}\text { European } \\
\text { Union, } \\
2021\end{array}$ \\
\hline & $\begin{array}{l}\text { 1) ICT contributes to the growth of the agricultural } \\
\text { sector } \\
\text { 2) ICT gives farmers valuable information about } \\
\text { the agricultural sector }\end{array}$ & $\begin{array}{l}\text { Das \& Kabir, } \\
2016\end{array}$ & $\begin{array}{l}\text { Improper recycling of ICT devices cause significant } \\
\text { environmental pollution in developing countries }\end{array}$ & $\begin{array}{l}\text { Williams, } \\
2011\end{array}$ \\
\hline & $\begin{array}{l}\text { 1) ICT provides real-time access to information } \\
\text { about market demand in the agricultural sector } \\
\text { 2) ICT provides information about long-term } \\
\text { market trends in the agricultural sector }\end{array}$ & $\begin{array}{l}\text { Kamande \& } \\
\text { Nafula, } \\
2016\end{array}$ & & \\
\hline
\end{tabular}

\section{Other Factors Impacting The Environment}

In this section, we review several studies that have investigated the impact of factors like population, industry, and $\mathrm{GDP}_{\text {on }} \mathrm{CO}_{2}$ emissions and energy consumption.

In one of these studies, Nagdeve (2007) examined the relationship between population and the environment by analyzing the trends of these factors in India from 1957 to 2006 . According to the results of this study, population growth has had a devastating impact on India's natural resources and reserves.

Zhou et al. (2010) estimated and analyzed the amount of $\mathrm{CO}_{2}$ emitted by the ammonia industry in China from 2005 to 2015 and discussed the vial policies and potentials for $\mathrm{CO}_{2}$ emission reduction in this field. Considering the availability of data and the unique features of the industry, these researchers decided to use a combination of Tiers 1 and 2 methods proposed by IPCC (International Panel on Climate Change) for calculating $\mathrm{CO}_{2}$ emissions of ammonia production. The results of this study confirmed that the Chinese ammonia industry produces significant amounts of $\mathrm{CO}_{2}$, but also showed that there is tremendous potential for $\mathrm{CO}_{2}$ emission reduction in this industry.

In a study by Narayan et al. (2010), these researchers used the panel method to investigate the long-term elasticity of the effects of energy consumption on GDP and vice versa for a group of 93 countries from 1980 to 2006 using seven panels. This study reported that in .approximately $59 \%$ of the examined countries, energy consumption had a statistically significant positive long-term effect on real GDP, and in about $61 \%$ of them, real GDP had a statistically significant positive long-term effect on energy consumption.

An empirical study by Zaman et al. (2011) investigated the interaction between population and environmental degradation in India, Pakistan, and Sri Lanka from 1985 to 2009 using the Im-Pesaran-Shin (IPS) unit root test. In this study, the long-term relationships were tested using the Pedroni Panel Cointegration method, and ultimately a seemingly unrelated regression equation model was used to investigate the effect of demographic indicators on environmental factors. The results of this study showed the destructive effect of population overgrowth on the environment.

Fang et al. (2013) used the four-stage DEA method proposed by Fried et al. (1999) to examine the effects of industry characteristics on the energy-saving targets of Taiwan's service sectors from 2001 to 2008. In this study, the Tobit regression model with panel data was used for analyses. This study reported that service industries that have a higher GDP also have higher energy overuse.

In a study by Mehrara (2014) the relationship between environment, economic growth, and openness in Iran from 1970 to 2011 was investigated using the autoregressive distributed lag (ARDL) method. The results of this study showed that GDP had the greatest impact on $\mathrm{CO}_{2}$ emissions in both short and long terms.

Ameyaw \& Yao (2018) examined the relationship between GDP and $\mathrm{CO}_{2}$ emissions in five West African countries from 2007 to 2014 using a panel data model. Based on the findings, these researchers concluded that there is a one-way causality relationship between $\mathrm{GDP}_{\text {and }} \mathrm{CO}_{2} \mathrm{emissions}$ Using this relationship, they predicted the future $\mathrm{CO}_{2}$ emissions of the studied countries and their future consumption levels.

In a study by Weber \& Sciubba (2019), the effect of population growth on $\mathrm{CO}_{2}$ emissions in 1062 regions of 22 European countries between 1990 and 2006 was analyzed by panel regressions, spatial econometric models, and propensity score matching. The results of these analyses showed different patterns in Western Europe and Eastern Europe. In Western Europe, urban growth increased with population growth, leading to increased $\mathrm{CO}_{2}$ emissions compared to smaller areas. But there was no such relationship in Eastern Europe, as the population was mostly declining.

Subartini et al. (2019) investigated the effect of GDP and population on $\mathrm{CO}_{2}$ emissions in Indonesia from 1967 to 2014 using the Cobb-Douglas model with the Particle Swarm Optimization (PSO) algorithm used for parameter estimation. According to the results of this study, $\mathrm{CO}_{2}$ emissions increase further with

Page $7 / 18$ 
GDP than with population.

Xu et al. (2012) studied the changes in energy consumption and $\mathrm{CO}_{2}$ emissions and their driving factors in the Chinese cement industry from 1990 to 2009 using the logarithmic mean Divisia index (LMDI). These researchers reported that the increase in cement production output is the most important cause of increasing energy consumption in the industry, whereas clinker share decline and structural shifts are the main causes of the decrease in energy consumption (the same is also true for $\mathrm{CO}_{2}$ emissions).

In a study by Chen et al. (2020), one of the research objectives was to identify the factors affecting the energy consumption of the agricultural industry in 89 countries from 2000 to 2016 . The results of this study showed that the economic output of agriculture is associated with an increase in energy consumption in the agricultural sector, but the other three studied factors (agricultural land, labor intensity, and energy intensity) reduce the energy consumption of this sector.

He et al. (2020) used an empirical strategy to study the impact of China's highway system on GDP growth in affluent and poor villages from 1984 to 2012. According to these researchers, highways give local governments an opportunity to strike a balance between GDP growth and environmental concerns. This is an opportunity for poor villages to increase their GDP, as they can host more polluting industries and promote industrialization at the cost of environmental quality. Affluent villages however can sacrifice part of their GDP to remain clean by rejecting the industries that emit GHGs and pollutants.

\section{Research Methodology And Model}

This study aimed to examine the relationship between ICT and the environment in high-income, middle-income, and low-income countries from 2005 to 2019. The Generalized Method of Moments (GMM) was used to estimate five models. The Sargan (1958) test proposed by Arellano and Bond was used to ensure the suitability of instrumental variables.

Taking inspiration from Avom et al. (2020), we investigated the effect of ICT on the environment by introducing a linear function comprised of the logarithm of $\mathrm{CO}_{2}$ emission $\left(\mathrm{Y}_{1}\right)$, ICT development Index (IDI), Gross Domestic Product (GDP), industry's share of total production (Ind), and population (Population):

$\operatorname{Ln}\left(Y_{1}\right)_{\text {it }}=\beta_{1} \operatorname{Ln}\left(Y_{1}\right)_{i, t-1}+\beta_{2} I D I_{i t}+\beta_{3} \operatorname{Ind}_{i t}+\beta_{4} G D P P_{i t}+\beta_{5}(\text { Population })_{i t}+\mathbb{Z}_{i t}(1)$

Here, $\mathrm{i}$ and $\mathrm{t}$ denote the country and year, and $\mathrm{Q}$ is the error term. The effect of IDI on other environmental variables was investigated as follows:

Definition of the model of $\mathrm{CO}_{2}$ emissions from solid fuel consumption:

Adjusted net savings, including particulate emission damage, Adjusted savings: energy depletion, Adjusted savings: carbon dioxide damage

The estimation was performed several times by removing and replacing environmental variables including $\mathrm{CO}_{2}$ emissions from liquid fuel consumption in Model 2, the logarithm of $\mathrm{CO}_{2}$ emissions from solid fuel consumption (\% of total) in Model 3, the logarithm of adjusted net savings including particulate emission damage (current US\$) in Model 4, adjusted savings: energy depletion (current US\$) in model 5, and adjusted savings: carbon dioxide damage (current US\$)

$\left(Y_{2}\right)_{i t}=\beta_{1}\left(Y_{2}\right)_{i, t-1}+\beta_{2} I D I_{i t}+\beta_{3} \operatorname{lnd}_{i t}+\beta_{4} G D P_{i t}+\beta_{5}(P O P U L A T I O N)_{i t}+\bigotimes_{i t}(2)$

$\operatorname{Ln}\left(Y_{3}\right)_{i t}=\beta_{1} \operatorname{Ln}\left(Y_{3}\right)_{i, t-1}+\beta_{2} I D I_{i t}+\beta_{3} \operatorname{Ind}_{i t}+\beta_{4} G P_{i t}+\beta_{5}(P O P U L A T I O N)_{i t}+\mathbb{B}_{i t}(3)$

$\operatorname{Ln}\left(Y_{4}\right)_{i t}=\beta_{1} \operatorname{Ln}\left(Y_{4}\right)_{i, t-1}+\beta_{2} I D I_{i t}+\beta_{3} \operatorname{Ind}_{i t}+\beta_{4} G D P P_{i t}+\beta_{5}(\text { POPULATION })_{i t}+\mathbb{V}_{i t}(4)$

$\operatorname{Ln}\left(Y_{5}\right)_{i t}=\beta_{1} \operatorname{Ln}\left(Y_{5}\right)_{i, t-1}+\beta_{2} I D I_{i t}+\beta_{3} \operatorname{Ind}_{i t}+\beta_{4} G P_{i t}+\beta_{5}(P O P U L A T I O N)_{i t}+\bigotimes_{i t}(5)$

$\mathrm{Y}_{2}: \mathrm{CO}_{2}$ (solid)

$\mathbf{Y}_{3}$ : Adjusted net savings, including particulate emission damage

$\mathrm{Y}_{4}$ : Adjusted savings: energy depletion

$\mathbf{Y}_{\mathbf{5}}$ : Adjusted savings: carbon dioxide damage

Descriptions of dependent and independent variables are provided in Tables 5 and 6, respectively. 
Table 5

Description of dependent variables

\begin{tabular}{|lll|}
\hline Variable name & unit & Source \\
\hline $\mathrm{CO}_{2}$ emissions & $\mathrm{kt}$ & World Bank \\
\hline $\mathrm{CO}_{2}$ emissions from solid fuel consumption & $\%$ of total & World Bank \\
\hline Adjusted net savings, including particulate emission damage & current US\$ & World Bank \\
\hline Adjusted savings: energy depletion & current US\$ & World Bank \\
\hline Adjusted savings: carbon dioxide damage & current US\$ & World Bank \\
\hline
\end{tabular}

Table 6

Description of independent variables

\begin{tabular}{|lll|}
\hline Variable name & unit & Source \\
\hline IDI (ICT Development Index) & - & Website of ITU and IDI 2017 Rank \\
\hline Population & ages 15-64 (\% of total population) & World Bank \\
\hline Industry(including construction) & $\%$ of GDP & World Bank \\
GDP & annual \% & World Bank \\
\hline
\end{tabular}

In this study, it was decided to measure ICT in terms of the ICT Development Index (IDI). Besides IDI, other variables that were assumed to have a positive effect on $\mathrm{CO}_{2}$ emissions and the consequent environmental impacts are population, GDP, and industry's share of total production (including construction).

\section{Data Description And Model Estimation}

To estimate the models, we needed the IDI data of countries with different income levels. One of the most challenging issues in determining the relationship between ICT and the environment is how to measure ICT development. The difficulty of this measurement stems from the definition of ICT development. In previous studies, researchers have measured ICT development with a variety of indicators including the number of landline users, mobile phone users, Internet users, households with computers, and households with Internet access at home, each of which indicates a different aspect of ICT development. In this study, this measurement was done in terms of the ICT Development Index (IDI), which was first introduced in the 2009 edition of the book "Measuring the Information Society".

This study is limited to 10 high-income countries, 10 middle-income countries, and 10 low-income countries in the period 2005-2019. The names of these countries and their income levels are provided in Table 7. The source of all income data used in this study is the World Bank. 
Table 7

Studied countries by GDP per capita

\begin{tabular}{|c|c|c|c|}
\hline Year & High-income & World Rank & GDP per capita (USD) \\
\hline 2018 & Switzerland & 1 & 83580 \\
\hline 2018 & Norway & 2 & 80790 \\
\hline 2018 & Luxembourg & 3 & 77820 \\
\hline 2018 & United States & 4 & 62850 \\
\hline 2018 & Denmark & 6 & 60140 \\
\hline 2018 & Singapore & 8 & 58770 \\
\hline 2018 & Sweden & 9 & 55070 \\
\hline 2018 & Germany & 14 & 47450 \\
\hline 2018 & Canada & 16 & 44860 \\
\hline \multirow[t]{2}{*}{2018} & United Kingdom & 18 & 41330 \\
\hline & Middle-income & & \\
\hline 2018 & Argentina & 52 & 12370 \\
\hline 2018 & Malaysia & 57 & 10460 \\
\hline 2018 & Turkey & 58 & 10380 \\
\hline 2018 & Russia & 59 & 10230 \\
\hline 2018 & Brazil & 65 & 9140 \\
\hline 2018 & Philippines & 110 & 3830 \\
\hline 2018 & Egypt & 124 & 2,800 \\
\hline 2018 & Ukraine & 125 & 2660 \\
\hline 2018 & Pakistan & 144 & 1580 \\
\hline \multirow[t]{2}{*}{2018} & Cameroon & 146 & 1440 \\
\hline & Low-income & & \\
\hline 2018 & Tanzania & 155 & 1020 \\
\hline 2018 & Tajikistan & 156 & 1010 \\
\hline 2018 & Nepal & 157 & 960 \\
\hline 2018 & Mali & 160 & 830 \\
\hline 2018 & Ethiopia & 163 & 790 \\
\hline 2018 & Rwanda & 164 & 780 \\
\hline 2018 & Chad & 167 & 670 \\
\hline 2018 & Togo & 169 & 650 \\
\hline 2018 & Niger & 178 & 380 \\
\hline 2018 & Malawi & 179 & 360 \\
\hline
\end{tabular}

Source: World Bank

\section{Model Estimation}

The model estimation method used in this paper is the dynamic panel data method. Before estimating the model, a cross-sectional dependency test must be performed. In panel data econometrics, it is generally assumed that there is cross-sectional independence between the available data. The cross-sectional interdependence can originate from sources such as external consequences, interdependence of uncalculated residuals, regional and economic relationships, and unobserved relationships between different sections. Thus, the first step of panel data econometrics is to detect cross-sectional independence in data. This can be done by various tests including those developed by Breusch \& Pagan (1980) and Pesaran (2004). In this article, the CD test of Pesaran (2004) was used for this purpose. This test is applicable to both balanced and unbalanced panel data. Also, unlike the test of Breusch \& Pagan (1980), this test provides reliable results for both large and small cross-sectional dimensions. 
The results of the cross-sectional dependence test of Pesaran (2004) for the studied data are provided in Table 8. The null hypothesis of this test is the absence of cross-sectional dependence for the tested variables. As these results demonstrate, the test showed cross-sectional dependence between all variables except population.

Table 8. Results of the cross-sectional dependence test of the variables of Model 1 for the period 2005-2019

\begin{tabular}{|c|c|c|}
\hline Significance (prob) & Statistic & Variable \\
\hline 0.0000 & 6.812276 & $\operatorname{Ln}\left(\mathrm{CO}_{2}\right)$ \\
\hline 0.0000 & 21.99308 & GDP \\
\hline 0.0000 & 15.15629 & Industry(including construction) \\
\hline 0.0000 & 65.03501 & IDI \\
\hline 0.4238 & 0.799830 & population \\
\hline
\end{tabular}

Source: research findings

It was also necessary to determine whether there is a cross-sectional dependence between the error terms of the model. For this purpose, the cross-sectional dependence test for these terms was performed in both fixed effects and random effects modes. The presence or absence of cross-sectional dependence between error terms can be assessed by various tests including the cross-sectional independence test of Pesaran (2004) and the cross-sectional dependence test of Breusch \& Pagan (1980). The answer to the question that which of these tests is more appropriate depends on the number of sections and time series in the research. If there are fewer time series than sections, the Pesaran test of cross-sectional independence will be more suitable; otherwise, it is better to use the other test (Pesaran, 2004). Since the data of this study belonged to 30 countries with different income levels for the period from 2005 to 2019 , we used the Pesaran test of cross-sectional independence (Pesaran, 2004) to check the existence or absence of cross-sectional dependence for error terms. The results of this test are presented in Tables 9 to 12 .

Table 9. Results of Pesaran test of cross-sectional independence for the error terms of IDI

\begin{tabular}{|l|l|l|l|}
\hline \multicolumn{3}{|c|}{ Random effects } & \multicolumn{2}{|c|}{ Fixed effects } \\
\hline Significance (prob) & statistic & Significance (prob) & statistic \\
\hline & & & \\
0.0000 & 6.195609 & 0.0000 & 6.201165 \\
& & & \\
\hline
\end{tabular}

Table 10. Results of Pesaran test of cross-sectional independence for the error terms of Industry

\begin{tabular}{|l|l|l|l|}
\hline \multicolumn{3}{|c|}{ Random effects } & \multicolumn{2}{|c|}{ Fixed effects } \\
\hline Significance (prob) & statistic & Significance (prob) & statistic \\
\hline & & & \\
& 8.0000 & 0.0000 & 7.729454 \\
& & & \\
\hline
\end{tabular}

Table 11. Results of Pesaran test of cross-sectional independence for the error terms of Population

\begin{tabular}{|l|l|l|l|}
\hline \multicolumn{3}{|c|}{ Random effects } & \multicolumn{2}{|c|}{ Fixed effects } \\
\hline Significance (prob) & statistic & Significance (prob) & statistic \\
\hline & & & \\
& 2.0171 & 0.0043 & 2.856162 \\
& & & \\
\hline
\end{tabular}

Table 12. Results of Pesaran test of cross-sectional independence for the error terms of GDP

\begin{tabular}{|l|l|l|l|}
\hline \multicolumn{3}{|c|}{ Random effects } & \multicolumn{2}{|c|}{ Fixed effects } \\
\hline Significance (prob) & statistic & Significance (prob) & statistic \\
\hline & & & \\
0.0000 & 7.020521 & 0.0000 & 7.077910 \\
& & & \\
\hline
\end{tabular}


As can be seen, cross-sectional dependence was detected in both fixed effects and random effects modes. Based on the above results, the existence of a panel co-integration relationship between the studied variables was confirmed.

Once the existence of cross-sectional dependence between the error terms of the studied variables in both fixed effects and random effects modes is verified, one can use GMM for model estimation. To make sure the accuracy of the selected estimation approach, the serial autocorrelation test and the Sargan test were performed at the end of the model estimation phase. It should also be noted that GMM controls the endogeneity of variables with high inter-variable correlation.

The results of the estimation of the five equations provided in Section 2 using GMM are presented in Table 13.

Table 13

Results of GMM for Equations 1 to 5

\begin{tabular}{|c|c|c|c|c|c|}
\hline Model 5 & Model 4 & Model 3 & Model 2 & Model 1 & Variable \\
\hline-.001301 & -.0056798 & -.0019591 & -.0045204 & -.000726 & IDI \\
\hline$(0.000)$ & $(0.007)$ & $(0.191)$ & $(0.005)$ & $(0.000)$ & \\
\hline .0236129 & .0724651 & .1182042 & .873863 & .0482898 & population \\
\hline$(0.000)$ & $(0.000)$ & $(0.013)$ & $(0.000)$ & $(0.000)$ & \\
\hline .0015647 & .1151782 & .0255762 & .0265358 & .0025991 & Industry (including construction) \\
\hline$(0.052)$ & $(0.000)$ & $(0.002)$ & $(0.001)$ & $(0.018)$ & \\
\hline .0057322 & .0221065 & .0706865 & .0953987 & .0052903 & GDP \\
\hline$(0.000)$ & $(0.000)$ & $(0.000)$ & $(0.000)$ & $(0.000)$ & \\
\hline \multirow[t]{2}{*}{-} & \multirow[t]{2}{*}{-} & \multirow[t]{2}{*}{-} & \multirow[t]{2}{*}{-} & .8105869 & $(\operatorname{Ln}(\operatorname{co} 2))_{\mathrm{i}, \mathrm{t}-1}$ \\
\hline & & & & $(0.000)$ & \\
\hline \multirow[t]{2}{*}{-} & \multirow[t]{2}{*}{-} & \multirow[t]{2}{*}{-} & .7199312 & - & $\left(\mathrm{CO}_{2}(\text { solid })\right)_{\mathrm{i}, \mathrm{t}-1}$ \\
\hline & & & $(0.000)$ & & \\
\hline \multirow[t]{2}{*}{-} & \multirow[t]{2}{*}{ - } & .4032713 & - & - & $(\text { Ln(including) })_{i, t-1}$ \\
\hline & & $(0.000)$ & & & \\
\hline \multirow[t]{2}{*}{-} & .3692832 & \multirow[t]{2}{*}{-} & \multirow[t]{2}{*}{-} & \multirow[t]{2}{*}{-} & \multirow[t]{2}{*}{$(\operatorname{Ln}(\text { energy depletion }))_{i, t-1}$} \\
\hline & $(0.000)$ & & & & \\
\hline .9460739 & - & - & - & - & $(\operatorname{Ln}(\text { carbon dioxide damage }))_{\mathrm{i}, \mathrm{t}-1}$ \\
\hline \multicolumn{6}{|l|}{$(0.000)$} \\
\hline Source: re & rch findir & & & & \\
\hline
\end{tabular}

The above table shows the effects of different factors on each of the studied environmental components and the contribution of each factor to variations with the other factors kept constant. Since not all dependent variables (environmental components) are of the same kind or have similar units, their values must not be summed up.

As shown in Table 13, the behavior of the dependent variables $\left(\mathrm{Ln}\left(\mathrm{CO}_{2}\right), \mathrm{CO}_{2}\right.$ (solid), $\mathrm{Ln}$ (including), $\mathrm{Ln}$ (energy depletion), and $\mathrm{Ln}$ (carbon dioxide damage) is influenced by their own behavior in the previous year. As expected, IDI has a negative effect on the dependent variables of Models 1 to 5 , and other variables (GDP, population, and Ind) have a positive effect on $\mathrm{CO}_{2}$ emissions. In other words, any increase in these variables is associated with an increase in $\mathrm{CO}_{2}$ emissions.

The negative sign of the multiplier of IDI in the above equations is indicative of the role of ICT development in reducing environmental pollution due to $\mathrm{CO}_{2}$ emissions in the studied countries. This conclusion is consistent with the results of Chowdhury (2012), Stewart (2015), Zhang \& Liu (2015), and Higón et al. (2017), but contradicts the findings of Arushanyan et al. (2014), Amri et al. (2019), and Avom et al. (2020). According to the results of Table 12, an improvement in IDI helps improve the environment through a reduction in particulate emission damage, $\mathrm{CO}_{2}$ emissions, and energy consumption. For each percent increase in IDI, we see a $0.07 \%, 0.45 \%, 0.19 \%, 0.56 \%$ and $0.13 \%$ decrease in the dependent variables of Models 1 to 5 , respectively. As mentioned in Section 2, since the advent of ICT has changed people's lifestyles and created many tools and opportunities for efficiency improvement, it can be expected to alleviate environmental degradation. For example, with the popularization of electronic books and newspapers, we consume much less physical resources in the publishing industry. Also, with the development of ICT and the increasing use of these technologies in transportation networks, one can expect a decrease in the $\mathrm{CO}_{2}$ emissions of these networks and the consequent damages and also the emissions of particulates, which are generally produced in heavy traffic in 
addition to industrial activities. Furthermore, by providing a platform for the advent and expansion of e-banking, e-shopping, e-commerce, and other such activities, ICT has made a huge contribution to reducing unnecessary travel. ICT also reduces the emission of $\mathrm{CO}_{2}$ and particulates by lowering energy intensity and promoting new forms of renewable energy sources by laying the foundation for efficiency and output improvement in renewable energy systems. An increase in IDI corresponds to an increase in the use of ICT in the creation of smart networks in a variety of fields, which will lead to reduced $\mathrm{CO}_{2}$ emissions and more efficient energy consumption and thus environmental sustainability. Increasing IDI (level of ICT utilization) in a variety of fields also triggers a substitution trend, which means the reorganization of production processes to make them more energy-efficient. In many industrial sectors, ICT can lead to dematerialization or the optimization of energy or resource usage through the substitution process. Meanwhile, the improvement of IDI can also lead to increased demand for electricity or the replacement of an old technology with a new technology with the same level of energy consumption. However, the IDI data of the studied countries showed a negative relationship between their IDI and their $\mathrm{CO}_{2}$ emissions.

In Equations 1 to 5, the variable "Population" has a significant positive effect on the emission of particulates and $\mathrm{CO}_{2}$ and the consequent damage as well as energy consumption. For each percent increase in population, the dependent variables of Models 1 to 5 increase by $4.82 \%, 87.3 \%, 11.82 \%, 7.24 \%$, and $2.36 \%$, respectively, which means more environmental pollution. An increase in population size (population growth) increases the emission of GHG and particulates and the consequent environmental damage by increasing the demand for food, wood, and energy, which tends to results in faster destruction of forests and other green spaces and more reliance on fossil fuels. Regarding energy use, it is important to not neglect the effect of population age structure. In fact, since production and consumption patterns tend to be age group dependent, the same is also true for energy consumption patterns. Since the age group considered in this study (15-64 years) constitutes the active portion of a normal population, their energy consumption tends to increase with economic growth and GDP. This is because this age group provides the labor force for most of the economic and social activities. Also, the energy consumption of the household sector of each country is a function of demographic characteristics of households in that country such as the total number of households (the higher the number of households, the higher the energy consumption). The results of this part of the study are consistent with the results of Weber \& Sciubba (2019), Zaman et al. (2011), Nagdeve (2007), and Subartini et al. (2019), which have found population growth to be a contributing factor to environmental degradation.

There is also a significant positive relationship between the industry's share of production and environmental variables in Models 1 to 5 . With each percent in this variable, the dependent variables of these models increase by $0.25 \%, 2.6 \%, 2.5 \%, 11.51 \%$, and $0.15 \%$, respectively, which indicate detrimental effects on the environment. These results, which show the direct effect of the industry's share of production on $\mathrm{CO}_{2}$ emissions, are more or less consistent with the results of several theoretical and empirical studies conducted in the countries. To explain this relationship, it can be argued that the manufacturing sector is an integral part of any economy with a huge impact on GDP and income levels. In some of the studied countries, an economic structure that is heavily dependent on an unsustainable manufacturing sector has caused significant environmental damages and problems in terms of air pollution and excessive energy consumption. The high energy intensity of the industrial sector in developing countries can be somewhat attributed to the low rate of technological progress towards more energy-efficient processes. The same argument can also be made for the increase in $\mathrm{CO}_{2}$ emissions and the resulting environmental pollution in these countries. Also, with the introduction of new industries to countries, especially developing countries, it is reasonable to expect an increase in the energy consumption of their industrial sectors. Furthermore, in industrial economies, there is a direct relationship between energy consumption in the industrial sector and major environmental issues. Inefficient consumption of fossil fuels and raw materials in unsustainable industries increases the amount of energy and resources lost for reaching a certain amount of industrial output. The disposal of industrial wastes also involves consuming some amounts of energy, which also plays a role in increasing the emission of $\mathrm{GHGs}$, especially $\mathrm{CO}_{2}$. This shows that there is no alternative to introducing cleaner fuels and technologies to the industrial sector. The increasing energy efficiency in the industrial sector of the studied countries can also result in reduced emissions by promoting the use of new mechanized methods and the use of electricity instead of fossil fuels. Zhou et al. (2010) have proven the association between the energy consumption of the industrial sector and the increase in its $\mathrm{CO}_{2}$ emissions. Fang et al. (2013) have also made a similar conclusion for Taiwanese service industries. The study of Xu et al. (2012) showed such an increase in energy consumption in a Chinese industry (cement) and examined the change in the industry's energy consumption. In this regard, Chen et al. (2020) confirmed the increase in the energy consumption of the agriculture industry. The findings of this part of the study are consistent with the results of the aforementioned studies.

The positive sign of the multiplier of GDP in Models 1 to 5 indicates that it has a significant positive effect on the dependent variables of these equations. According to the results, a $1 \%$ increase in GDP will increase the dependent variables of Models 1 to 5 by $0.52 \%, 9.53 \%, 7.06 \%, 2.21 \%$ and $0.57 \%$, respectively. Regarding the impact of GDP on $\mathrm{CO}_{2}$ emissions, it can be argued that since many of the studied countries have a growing industrial sector or undergoing industrialization, the share of the industrial sector in the GDP of these countries account for a greater portion of their $\mathrm{CO}_{2}$ and particulate emissions. Also, the rising living standards and industrial growth in these countries and the resulting GDP improvement have led to more widespread adoption of energy-intensive consumption patterns. Although there is a relationship between energy consumption and GDP in both developed and developing countries, the amount of energy consumption very much depends on the extent of development. Since the studied countries have different levels of development, the relationship between energy consumption and GDP differs from case to case. The major surge in energy consumption usually occurs in the early stages of economic growth. Then, with the improvement of public awareness and sensitivity, the stabilization of environmental effects, and the improvement of education on energy use, the energy consumption becomes less intense through better optimization. Meanwhile, as the domestic production of countries increases, so does the demand for capital and energy consumption. If the production growth is not accompanied by any of the mentioned processes, it will cause environmental damage in addition to economic development. The results of this part of the study are consistent with the results of He et al. (2020), which confirmed the negative impact of rising GDP on environmental quality. Ameyaw \& Yao (2018) also reported a one-way causality relationship between $\mathrm{GDP}_{\text {and }} \mathrm{CO}_{2}$ emissions. According to Mehrara (2014), GDP has an impact on $\mathrm{CO}_{2}$ emissions over both short term and long term periods. Subartini et al. (2019) have also reported that GDP has an impact on $\mathrm{CO}_{2}$ emissions. Regarding the relationship between GDP and energy consumption, the results of this study are consistent with the finding of Narayan et al. (2010), which reported that real GDP had a significant positive effect on long-term energy consumption in about $61 \%$ of the countries they studied. 
Equations 1 to 5 were estimated using GMM and panel data. Of course, the estimations of GMM are only valid if there is no serial autocorrelation in error terms. Arellano and Bond (1991) have proposed a test for finding second-order autocorrelation. Since the null hypothesis of this test is the absence of serial autocorrelation, the second-order auto-regression statistic (AR(2)) should not be significant. If there is a second-order autocorrelation, then the moment conditions for the Arellano-Bond test of autocorrelation are not satisfied (Arellano and Bond, 1991).

The results of the Arellano-Bond test of second-order autocorrelation for the five formulated equations are presented in the table below.

Table 14

Results of Arellano-Bond test of second-order autocorrelation for Equations 1-5

\begin{tabular}{|llllllllllll|}
\hline & Model 5 & \multicolumn{3}{c}{ Mode 4 } & \multicolumn{5}{c|}{ Mode 3 } & \multicolumn{3}{c|}{ Model 2 } & & Model 1 & Arellano-Bond test \\
\hline Prob $>\mathrm{z}$ & $\mathrm{z}$ & Prob $>\mathrm{z}$ & $\mathrm{z}$ & Prob $>\mathrm{z}$ & $\mathrm{z}$ & Prob $>\mathrm{z}$ & $\mathrm{z}$ & Prob $>\mathrm{z}$ & $\mathrm{z}$ & \\
\hline 0.9172 & -.10399 & 0.0317 & -2.1482 & 0.3264 & .98148 & 0.1326 & -1.504 & 0.8178 & -.23034 & \\
\hline
\end{tabular}

As shown in Table 14, the second-order autoregression coefficient was found to be above $5 \%$, which indicates the absence of second-order serial autocorrelation. Using the above results, the null hypothesis that there is no serial autocorrelation of the first-order between error terms was verified and it was concluded that there is no correction bias in any of them.

Furthermore, the Sargan test (1958) was used to check the validity of instrumental variables. This test is commonly used to make sure of the proper selection of instrumental variables. The results of the Sargan test for the equations are presented in Table 15.

Table 15

Results of Sargan test for Equations 1-5

\begin{tabular}{|llllll|}
\hline Model 5 & Model 4 & Model 3 & Model 2 & Model 1 & Sargan \\
\hline 27.91776 & 21.55651 & 23.16525 & 27.90406 & 25.08607 & chi2(77) \\
\hline 1.0000 & 1.0000 & 1.0000 & 0.9991 & 0.9999 & Prob > chi2 \\
\hline
\end{tabular}

Using the results of Table 15, the null hypothesis that the chosen instrumental variables are valid in estimating the research models was confirmed. This verifies the validity of the findings for interpretation.

\section{Conclusion}

Recent years have seen a remarkable improvement in ICT penetration in the majority of countries across the world regardless of their income levels. While increased ICT penetration tends to create interesting challenges and opportunities in economic, social, and energy dimensions, it is also important to examine the role of ICT in reducing or increasing emissions. To explore this role, this study investigated the effect of the ICT Development Index (IDI) on five environmental variables in three groups of high, middle, and low-income countries from 2005 to 2019 . The results of model estimation with panel GMM showed the positive effect of IDI in reducing environmental damage in the studied countries. In other words, this index has a negative effect on total $\mathrm{CO}_{2}$ emissions, $\mathrm{CO}_{2}$ emissions from solid fuel consumption, $\mathrm{CO}_{2}$ emission damage, particulate emission damage, and energy consumption in these countries. These findings are consistent with the results of Zhou et al. (2019), Bastida et al., (2019), and Haini (2021) but contradict the results of Arushanyan et al., (2014), Amri et al. (2019), and Avom et al. (2020). This discrepancy in findings can be attributed to the difference between the studied countries or the studied periods. Another reason for this difference could be the devastating environmental effects of ICT penetration in countries where this process has been combined with inefficient energy use, high dependence on fossil fuels, and excessive electricity consumption. ICT can affect the emission of $\mathrm{CO}_{2}$ and other pollutants indirectly by affecting energy consumption levels.

Some production processes and human activities have always had devastating effects on the environment. Considering this and the dependence of industrial growth and development on the consumption of massive amounts of resources and fossil fuels, which have their own environmental impacts, ICT provides an interesting platform for the development of modern tools that experts can utilize to reduce the environmental impacts of industrial processes. Other studied variables, namely GDP, population, and industry's share of production, were also found to have a significant positive effect on environmental degradation in the formulated $\mathrm{CO}_{2}$ emission and energy consumption equations. In some of the studied countries, the absence of favorable conditions and proper infrastructure make it difficult to find a good replacement for activities that are energy-intensive or waste natural resources. Thus, it is essential to implement policies and programs that are effective in mitigating environmental changes.

Overall, the findings of this study showed the exceptional impact of ICT penetration on reducing energy consumption, reducing $\mathrm{CO}_{2}$ emissions and the consequent damages, and also reducing the emissions of other pollutants. This paper recommends the following policies for progress in this area.

Since it could be very beneficial to replace the existing outdated technologies with smart technologies that also reduce energy consumption, policymakers can significantly reduce environmental degradation by formulating policies that promote energy efficiency in the field of ICT and other energy-intensive sectors. Furthermore, the use of renewable energies and modern equipment instead of existing technologies can have a direct impact on the emission of particulates 
and carbon dioxide. Governments can also contribute to reducing energy consumption and emissions by promoting online exchanges and reducing restrictions on the import of modern equipment and technologies that facilitate such processes. Governments can also push for more energy efficiency through ICT by adopting policies that limit outdated technologies and processes. For certain countries, it might be advantageous to focus exclusively on acquiring modern industrial and energy generation technologies and implementing green ICT projects. Governments can also enhance the impact of ICT at the public level by creating programs that raise public awareness about environmental issues and their consequences or facilitate public access to modern technologies with less environmental impacts. Building ICT infrastructure, improving the indicators of ICT development, and pursuing better environmental compatibility in this area are some of the goals that must be given higher priority in the environmental protection agenda. Also, with the increasing environmental awareness of the ICT sector and the increasing use of ICT in the service of environmental goals, it is time to find a way to recycle electronic wastes more properly in order to significantly reduce their environmental impacts.

One of the limitations of this study was that it did not consider how the characteristics of each country affect the impact of ICT on its environment. This could be important because ICT infrastructure and public investment in this field differ from country to country, which means different countries do not have the same level of access to this technology. Therefore, future studies can expand on this research by conducting their analyses for individual countries in order to gain better insights into the effectiveness of policies at this level.

\section{Declarations}

Ethical Approval: Not applicable

Consent to Participate: Not applicable

Consent to Publish: All authors read the fnal version of the manuscript and approved it.

Authors' contributions: Sakineh Sojoodi: Initial idea generation and title selection, Collection of subject literature, Supervision of data collection and analysis, Control of final version. Samaneh Mahdavi: Collection of subject literature, Data collection, Data analysis, Writing and preparation of final version.

Funding: This research did not receive any specific grant from funding agencies in the public, commercial, or not-for-profit sectors.

Competing interests: The authors declare that they have no competing interests" in this section.

Availability of data and materials: The datasets used and/or analyzed during the current study are available from the corresponding author on reasonable request.

\section{References}

Alant, B. P., \& Bakare, O. O. (2021). A case study of the relationship between smallholder farmers' ICT literacy levels and demographic data wrt their use and adoption of ICT for weather forecasting. Heliyon, 7(3), e06403. https://www.sciencedirect.com/science/article/pii/S2405844021005089

Ameyaw, B., \& Yao, L. (2018). Analyzing the impact of GDP on $\mathrm{CO} 2$ emissions and forecasting Africa's total CO2 emissions with non-assumption driven bidirectional long short-term memory. Sustainability, 10(9), 3110. https://www.mdpi.com/2071-1050/10/9/3110

Amri, F., Zaied, Y. B., \& Lahouel, B. B. (2019). ICT, total factor productivity, and carbon dioxide emissions in Tunisia. Technological Forecasting and Social Change, 146, 212-217. https://www.sciencedirect.com/science/article/abs/pii/S0040162518307534

Arellano, M., \& Bond, S. (1991). Some tests of specification for panel data: Monte Carlo evidence and an application to employment equations. The review of economic studies, 58(2), 277-297. https://academic.oup.com/restud/article-abstract/58/2/277/1563354

Arnfalk, P. (1999). Information technology in pollution prevention: Teleconferencing and telework used as tools in the reduction of work related travel. IIIEE DISSERTATION, (1999: 1). https://trid.trb.org/view/685740

Arnfalk, P. (2002), Virtual Mobility and Pollution Prevention, Phd dissertation, International Institute of Industrial Environmental Economics, Lund University, Lund. https://portal.research.lu.se/portal/en/publications/virtual-mobility-and-pollution-prevention-the-emerging-role-of-ict-based-communication-inorganisations-and-its-impact-on-travel(5b63436b-ae95-465e-9311-3d9d2be9dd9a)/export.html

Arushanyan, Y., Ekener-Petersen, E., \& Finnveden, G. (2014). Lessons learned-Review of LCAs for ICT products and services. Computers in industry, 65(2), 211234. https://www.sciencedirect.com/science/article/abs/pii/S0166361513002133

Asongu, S. A., Le Roux, S., \& Biekpe, N. (2018). Enhancing ICT for environmental sustainability in sub-Saharan Africa. Technological Forecasting and Social Change, 127, 209-216. https://www.sciencedirect.com/science/article/abs/pii/S0040162517304845

Avom, D., Nkengfack, H., Fotio, H. K., \& Totouom, A. (2020). ICT and environmental quality in Sub-Saharan Africa: Effects and transmission channels. Technological Forecasting and Social Change, 155, 120028. https://www.sciencedirect.com/science/article/abs/pii/S0040162519316257

Bastida, L., Cohen, J. J., Kollmann, A., Moya, A., \& Reichl, J. (2019). Exploring the role of ICT on household behavioural energy efficiency to mitigate global warming. Renewable and Sustainable Energy Reviews, 103, 455-462. https://www.sciencedirect.com/science/article/abs/pii/S1364032119300073 
Becchetti, L., \& Auci, S. (2005). The Stability of the Adjusted and Unadjusted Environmental Kuznets Curve (No. 93.2005). Nota di Lavoro. https://www.econstor.eu/handle/10419/73951

Bekaroo, G., Bokhoree, C., \& Pattinson, C. (2016). Impacts of ICT on the natural ecosystem: A grassroot analysis for promoting socio-environmental sustainability. Renewable and Sustainable Energy Reviews, 57, 1580-1595. https://www.sciencedirect.com/science/article/abs/pii/S1364032115015300

Bonvoisin, J., Lelah, A., Mathieux, F., \& Brissaud, D. (2014). An integrated method for environmental assessment and ecodesign of ICT-based optimization services. Journal of cleaner production, 68, 144-154. https://www.sciencedirect.com/science/article/abs/pii/S0959652614000122

Breusch, T. S., \& Pagan, A. R. (1980). The Lagrange multiplier test and its applications to model specification in econometrics. The review of economic studies, 47(1), 239-253. https://www.jstor.org/stable/2297111

Casagrandi, R., \& Guariso, G. (2009). Impact of ICT in Environmental Sciences: A citation analysis 1990-2007. Environmental Modelling \& Software, 24(7), 865-871. https://www.sciencedirect.com/science/article/abs/pii/S136481520800217X

Center, A. D. P., \& Labelle, R. (2013). ICT, Climate Change and Green Growth. https://www.unapcict.org/sites/default/files/201908/Academy\%202.0\%20Module\%2010.pdf

Chen, X., Shuai, C., Zhang, Y., \& Wu, Y. (2020). Decomposition of energy consumption and its decoupling with economic growth in the global agricultural industry. Environmental Impact Assessment Review, 81, 106364. https://www.sciencedirect.com/science/article/abs/pii/S0195925519304019

Chowdhury, G. (2012). An agenda for green information retrieval research. Information Processing \& Management, 48(6), 1067-

1077. https://www.sciencedirect.com/science/article/abs/pii/S0306457312000192

Costantini, V., \& Martini, C. (2010). A modified environmental Kuznets curve for sustainable development assessment using panel data. International Journal of Global Environmental Issues, 10(1-2), 84-122. https://www.inderscienceonline.com/doi/abs/10.1504/IJGENVI.2010.030569

Das, S., Munshi, M. N., \& Kabir, W. (2016). The impact of ICTs on agricultural production in Bangladesh: A study with food crops. SAARC Journal of Agriculture, 14(2), 78-

89. https://www.researchgate.net/publication/312625724_The_impact_of_ICTs_on_agricultural_production_in_Bangladesh_A_study_with_food_crops

European Commission (2021), CORDIS EU research result. https://cordis.europa.eu/article/id/22998-icts-could-have-positive-or-negative-impact-onenvironmental-sustainability-finds-report

Fang, C. Y., Hu, J. L., \& Lou, T. K. (2013). Environment-adjusted total-factor energy efficiency of Taiwan's service sectors. Energy Policy, 63, $1160-1168$. https://www.sciencedirect.com/science/article/pii/S0301421513007830

Freitag, C., Berners-Lee, M., Widdicks, K., Knowles, B., Blair, G., \& Friday, A. (2021). The climate impact of ICT: A review of estimates, trends and regulations. arXiv preprint arXiv:2102.02622. https://arxiv.org/abs/2102.02622

Gay, R. H., Davis, R. A., Phillips, D. T., \& Sui, D. Z. (2005). Modeling paradigm for the environmental impacts of the digital economy. Journal of Organizational Computing and Electronic Commerce, 15(1), 61-82. https://www.tandfonline.com/doi/abs/10.1207/s15327744joce1501_4

Gelenbe, E., \& Caseau, Y. (2015). The impact of information technology on energy consumption and carbon emissions. Ubiquity, 2015(June), 115. https://dl.acm.org/doi/abs/10.1145/2755977

Haini, H. (2021). Examining the Impact of ICT, Human Capital and Carbon Emissions: Evidence from the ASEAN Economies. International Economics. https://www.sciencedirect.com/science/article/abs/pii/S2110701721000196

Han, B., Wang, D., Ding, W., \& Han, L. (2016). Effect of information and communication technology on energy consumption in China. Natural Hazards, 84(1), 297-315. https://link.springer.com/article/10.1007/s11069-016-2188-1

He, G., Xie, Y., \& Zhang, B. (2020). Expressways, GDP, and the environment: The case of China. Journal of Development Economics, $145,102485$. https://www.sciencedirect.com/science/article/abs/pii/S0304387820300602

Higón, D. A., Gholami, R., \& Shirazi, F. (2017). ICT and environmental sustainability: A global perspective. Telematics and Informatics, 34(4), 85-95. https://www.sciencedirect.com/science/article/abs/pii/S0736585316305846

Houghton, J. W. (2010). ICT and the environment in developing countries: A review of opportunities and developments. What kind of information society? Governance, virtuality, surveillance, sustainability, resilience, 236-247.

https://www.researchgate.net/publication/220939749_ICT_and_the_Environment_in_Developing_Countries_A_Review_of_Opportunities_and_Developments

Kamande, M., \& Nafula, N. (2016). The welfare effects of ICTs in agricultural markets: A case of selected countries in East Africa (No. 35). International Food Policy Research Institute (IFPRI). https://ideas.repec.org/p/fpr/agrowp/35.html

Kante, M., Oboko, R., \& Chepken, C. (2016). Factors affecting the use of ICTs on agricultural input information by farmers in developing countries. AIMS Agriculture and Food, 1(3), 315-329. https://www.aimspress.com/fileOther/PDF/agriculture/agrfood-01-00315.pdf 
Khan, N., Baloch, M. A., Saud, S., \& Fatima, T. (2018). The effect of ICT on CO 2 emissions in emerging economies: does the level of income matters?. Environmental Science and Pollution Research, 25(23), 22850-22860. https://link.springer.com/article/10.1007/s11356-018-2379-2

Kumar, Rakesh and Mieritz Lars (2007), “Conceptualizing Green IT and Data Centre Power and Cooling Issues”, Gartner Research Paper No. G00150322. https://www.scirp.org/(S(351jmbntvnsjt1aadkposzje))/reference/ReferencesPapers.aspx?ReferencelD=1631835

Lashkarizadeh, M., \& Salatin, P. (2012). The Effects of Information and Communications Technology (ICT) on Air Pollution. Elixir Pollution, 46, 80588064. https://www.elixirpublishers.com/articles/1350374116_46\%20(2012)\%208058-8064.pdf

López, R., Galinato, G. I., \& Islam, A. (2011). Fiscal spending and the environment: theory and empirics. Journal of Environmental Economics and Management, 62(2), 180-198. https://www.sciencedirect.com/science/article/abs/pii/S009506961100026X

Majeed, M. T. (2018). Information and communication technology (ICT) and environmental sustainability: a comparative empirical analysis. Pakistan Journal of Commerce and Social Sciences (PJCSS), 12(3), 758-783. https://www.proquest.com/openview/cd914aebdbc48711f16012e3671b793f/1?pqorigsite $=$ gscholar $\&$ cbl $=1576351$

Marin, G. (2010). Sector CO2 and SOx emissions efficiency and investment: homogeneous vs heterogeneous estimates using the Italian NAMEA. https://mpra.ub.uni-muenchen.de/24077/

Mehrara, M. (2014). The Relationship between GDP, Globalization and Environment. International Journal of Applied, 2(3).

https://web.archive.org/web/20180409204942id_/http://sijournals.com/IJAE/wp-content/uploads/2014/08/01-The-Relationship-between-GDP-Globalizationand-Environment.pdf

Monzon, A., Garcia-Castro, Á., \& Valdes, C. (2017). Methodology to assess the effects of ICT-measures on emissions. The case study of Madrid. Procedia Engineering, 178, 13-23. https://www.sciencedirect.com/science/article/pii/S1877705817300541

Moyer, J. D., \& Hughes, B. B. (2012). ICTs: do they contribute to increased carbon emissions?. Technological Forecasting and Social Change, 79(5), 919-931. https://www.sciencedirect.com/science/article/abs/pii/S0040162511002836

Nagdeve, D. A. (2007). Population growth and environmental degradation in India. International Institute for Population Sciences. http://paa2007. princeton. edu/papers/7192. Department of fertility studies, Govandi station road, Deonar, Mumbai, 400, 088. https://www.researchgate.net/profile/Arvind-Singh21/post/What_is_the_role_of_population_growth_in_environmental_degradation_today/attachment/5ace505ab53d2f63c3c53e8d/AS\%3A614293645041712\%

Narayan, P. K., Narayan, S., \& Popp, S. (2010). A note on the long-run elasticities from the energy consumption-GDP relationship. Applied Energy, 87(3), 10541057. https://www.sciencedirect.com/science/article/abs/pii/S0306261909003651

OECD (2001), "Impacts of Information and Communication Technologies on Environmental Sustainability: Speculations and Evidence", Report to the OECD. https://www.oecd.org/sti/inno/1897156.pdf

Ozcan, B., \& Apergis, N. (2018). The impact of internet use on air pollution: evidence from emerging countries. Environmental Science and Pollution Research, 25(5), 4174-4189. https://link.springer.com/article/10.1007/s11356-017-0825-1

Pesaran, M. H. (2004). General diagnostic tests for cross section dependence in panels (IZA Discussion Paper No. 1240). Institute for the Study of Labor (IZA). https://ftp.iza.org/dp1240.pdf

Qureshi, S. (2019). Climate change adaptation for sustainable development: the information and communication technology (ICT) paradox. https://www.tandfonline.com/doi/full/10.1080/02681102.2019.1680164

Rodhain, F., \& Fallery, B. (2009). ICT and Ecology: In favour of research based on the Responsibility principle. In MCIS 2009 (pp. 173-186). https://hal.archivesouvertes.fr/hal-00777858/

Romm, J. (2002). The internet and the new energy economy. Resources, conservation and recycling, 36(3), 197-210.

https://www.sciencedirect.com/science/article/abs/pii/S0921344902000848

Sadorsky, P. (2012). Information communication technology and electricity consumption in emerging economies. Energy Policy, 48, 130-

136. https://www.sciencedirect.com/science/article/abs/pii/S0301421512003692

Sargan, J. D. (1958). The estimation of economic relationships using instrumental variables. Econometrica: Journal of the Econometric Society, $393-415$. https://www.jstor.org/stable/1907619

Schulte, P., Welsch, H., \& Rexhäuser, S. (2016). ICT and the Demand for Energy: Evidence from OECD Countries. Environmental and resource economics, 63(1), 119-146. https://link.springer.com/article/10.1007/s10640-014-9844-2?

error=cookies_not_supported\&error=cookies_not_supported\&error=cookies_not_supported\&error=cookies_not_supported\&code=5b5bbf62-92fa-4a29-a4efbd41e717eb77\&code=8120a56f-57c3-4a93-b316-a2ed3b407a90\&code=1cbf5827-bb18-484d-8d07-1ba79b21598f\&code=1b355a43-b08c-45a7-ba31$3492 \mathrm{e} 367 \mathrm{~b} 879$ 
Stewart, K. (2015). Assessing the carbon impact of ICT measures: a case study investigation using Latis model. International Journal of Transportation Science and Technology, 4(3), 277-294. https://www.sciencedirect.com/science/article/pii/S2046043016301289

Subartini, B., Supian, S., Napitupulu, H., Budiono, R., \& Juahir, H. (2019, August). Modeling of the impact of GDP and human population on CO2 emission by using Cobb-Douglas model and particle swarm optimization. In IOP Conference Series: Earth and Environmental Science (Vol. 311, No. 1, p. 012080). IOP Publishing. https://iopscience.iop.org/article/10.1088/1755-1315/311/1/012080/meta

Takahashi, K. I., Tatemichi, H., Tanaka, T., Nishi, S., \& Kunioka, T. (2004, May). Environmental impact of information and communication technologies including rebound effects. In IEEE International Symposium on Electronics and the Environment, 2004. Conference Record. 2004 (pp. 13-16).

IEEE. https://www.google.com/url?

sa=t\&rct=j\&q=\&esrc=s\&source=web\&cd=\&cad=rja\&uact=8\&ved=2ahUKEwingp71y5XzAhX5BGMBHe2CBpEQFnoECAIQAQ\&url=https\%3A\%2F\%2Fwww.semant impact-of-information-and-including-Takahashi-Tatemichi\%2F1289aaf2ea72b2bd720e39b117a11332ef9142ce\&usg=AOvVaw18iMTcpTjtclss5gWU-I1H

Toffel, M. W., \& Horvath, A. (2004). Environmental implications of wireless technologies: news delivery and business meetings. Environmental Science \& Technology, 38(11), 2961-2970. https://pubs.acs.org/doi/abs/10.1021/es035035o

Wang, D., \& Han, B. (2016). The impact of ICT investment on energy intensity across different regions of China. Journal of renewable and sustainable energy, 8(5), 055901. https://aip.scitation.org/doi/abs/10.1063/1.4962873

Weber, H., \& Sciubba, J. D. (2019). The effect of population growth on the environment: evidence from European regions. European Journal of Population, 35(2), 379-402. https://link.springer.com/article/10.1007/s10680-018-9486-0

Wong, J., \& Schuchard, R. (2011). Adapting to Climate Change: A Guide for the ICT

Industry. https://www.bsr.org/reports/BSR_Climate_Change_Adaptation_ICT.pdf

Williams, E. (2011). Environmental effects of information and communications technologies. Nature, 479(7373), $354-358$.

https://www.nature.com/articles/nature10682

Xu, J. H., Fleiter, T., Eichhammer, W., \& Fan, Y. (2012). Energy consumption and CO2 emissions in China's cement industry: A perspective from LMDI decomposition analysis. Energy policy, 50, 821-832. https://www.sciencedirect.com/science/article/abs/pii/S0301421512007203

Yi, L., \& Thomas, H. R. (2007). A review of research on the environmental impact of e-business and ICT. Environment international, 33(6), 841849. https://www.sciencedirect.com/science/article/pii/S0160412007000736

Yılmaz, R., \& Koyuncu, C. (2019). The impact of ICT penetration on deforestation: A panel data evidence. Review of Economic Perspectives, 19(4), 345-364. https://www.econstor.eu/handle/10419/227535

Zaman, K., Khan, H., Khan, M. M., Saleem, Z., \& Nawaz, M. (2011). The impact of population on environmental degradation in South Asia: application of seemingly unrelated regression equation model. Environmental economics, (2, Iss. 2), 80-88. http://www.irbis-nbuv.gov.ua/cgi-bin/irbis_nbuv/cgiirbis_64.exe? C21COM=2\&I21DBN=UJRN\&P21DBN=UJRN\&IMAGE_FILE_DOWNLOAD=1\&Image_file_name=PDF/envirecon_2011_2_2_10.pdf

Zhang, C., \& Liu, C. (2015). The impact of ICT industry on CO2 emissions: a regional analysis in China. Renewable and Sustainable Energy Reviews, 44, 1219. https://www.sciencedirect.com/science/article/abs/pii/S1364032114010636

Zhou, W., Zhu, B., Li, Q., Ma, T., Hu, S., \& Griffy-Brown, C. (2010). CO2 emissions and mitigation potential in China's ammonia industry. Energy Policy, 38(7), 3701-3709. https://www.sciencedirect.com/science/article/abs/pii/S0301421510001527 